\title{
OBITUARY
}

\section{Phillip Tobias}

In mourning the loss of a much loved and respected friend and colleague, it is appropriate to celebrate his well-lived life of distinction, filled with many exceptional achievements.

As an unusually bright and inquisitive schoolboy, Phillip Tobias developed interests in writing, nature, science, anatomy, genetics and archaeology. An accident at the age of nine, which resulted in three months in hospital, gave him early personal insights into the value of care and compassion in medicine. Although his childhood environment presented many challenges, Phillip overcame these and developed a principled outlook on life. This was supported by insights from his religious heritage, and by others' recognition of his intellectual qualities. A family history of diabetes, the death of his sister at the age of 21 after suffering from diabetes for only a few years, and an exhibition on genetics at the Natural History Museum in Durban, set him along the path of his ambition to become the first medical geneticist in South Africa.

Phillip's early academic credentials were a prelude to what would become a remarkable career. Incorporation of a BSc (Hons) in Histology and Physiology into his studies towards the MB BCh enabled him to work towards a $\mathrm{PhD}$ by dissertation ('Chromosomes, Sex-cells and Evolution in the Gerbil') awarded only three years after qualifying in medicine. His scientific training was complemented by the emphasis on astute observational and deductive skills aspired to by physicians in an era of medicine when accurate clinical diagnosis was the key to effective practice. This educational path, followed by post-graduate research in the UK and the USA, and a Rockefeller travelling fellowship completed his eligibility for an academic leadership position.

He became Professor and Head of Anatomy and Human Biology at the University of the Witwatersrand (Wits) at the age of 34, succeeding Professor Raymond Dart, who had discovered the first known australopithecine. The combination of acquiring empirical knowledge and developing observational and analytical skills for application to structures and their functional relationships, led to the production of a textbook of anatomy that was used avidly by many generations of medical students.
Professor Tobias may be best known for his meticulous, detailed and wide-ranging research work as a palaeoanthropologist on the human biology of various populations in Africa. With Louis and Mary Leakey he reported the discovery of Homo habilis in 1964. He went on to study hominid fossils at the Sterkfontein caves and at many archaeological sites in southern Africa, received a DSc from Wits for his work on hominid evolution in 1967 and published prolifically - many hundreds of articles and over 30 books. His popular six-part TV series, Tobias' Bodies, exploring different themes around genetics, anatomy and primatology, was widely acclaimed.

His critical questioning approach to the pursuit of major questions about the origin and meaning of life, his concern for his students and fellow humans and his integrity were characteristic features of the way he lived and worked.

His decision to remain in South Africa (a country that he loved), his activities in student and university affairs throughout his long career, and his sensitivity to the physical and social history of humankind, were combined with fairness and compassion in dealing with his fellows. His dedicated and outspoken role in opposing apartheid, and in the Biko affair (with several close colleagues), added another dimension to the excellence and integrity for which he became renowned and that he brought to the Deanship of the Wits Medical School from 1980 to 1982.

Anthony Paton, deputy director of the Cradle of Humankind World Heritage Site and Dinokeng Projects, has described Phillip Tobias as a man whose life was dignified, distinguished and indisputably ethical and whose works have been prolific and profound'

The number, variety and sources of many honorary degrees, prestigious awards and accolades he received made him the best known and most widely (and arguably, lovingly) celebrated South African physician, scientist and humanist. His legacy of thousands of students, who could be considered as his intellectual offspring, will contribute to advancing his ideas and ideals.

\section{Solomon Benatar \\ Emeritus Professor of Medicine \\ University of Cape Town}

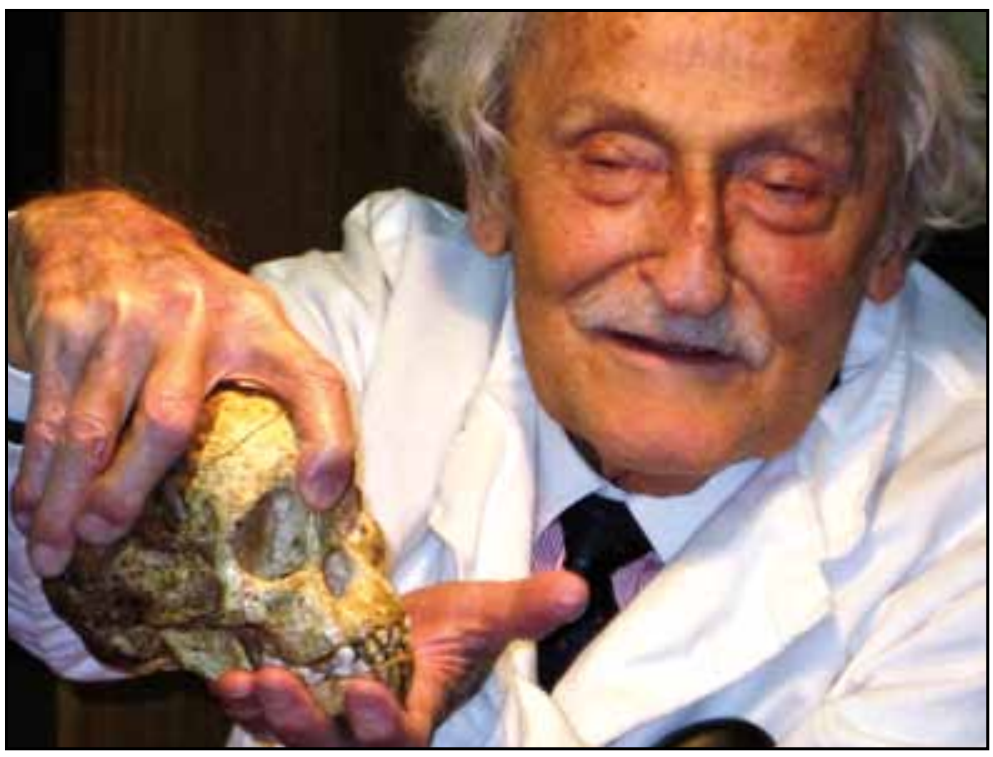

